Nevşehir Bilim ve Teknoloji Dergisi TARGíd Özel Sayı 295-302 2016

DOI: 10.17100/nevbiltek.211012

URL: http://dx.doi.org/10.17100/nevbiltek.211012

\title{
Türkiye’deki Doğal Bitki Türlerinin Üretiminde Doku Kültürü Tekniklerinin Kullanımı
}

\author{
Deryanur Dinçer, Banu Bekçi, Fatih Bekiryazıcı ${ }^{1}$ \\ Recep Tayyip Erdoğan Üniversitesi, Güzel Sanatlar, Tasarım ve Mimarllk Fakültesi, Peyzaj Mimarllğı Bölümü, \\ Rize
}

Öz

Floristik zenginlik bakımından sahip olduğu doğal tür sayısı ile Türkiye, dünya sıralamasında başta gelen ülkelerden biridir. Bu türlerden bazıları aromatik, farmakolojik, tıbbi ve besin olarak kullanımlarının yanı sıra, Peyzaj Mimarlığı açısından potansiyel süs bitkisi olarak oldukça değerlidirler. Bu doğal türlerimizin büyük bir çoğunluğu henüz kültüre alınmamış yada alınamamış, sadece kırsal peyzajda kalmış yabani türler şeklindedir. Ayrıca, artan nüfus ve gelişen endüstrileşme bu doğal bitki türlerinin büyüme ortamlarının bozulmasına ve hatta bazı türlerin bilinçsizce doğadan yoğun bir şekilde toplanması nedeniyle neslinin tehlikeye girmesine neden olmuştur. Bu olumsuzlukların ortadan kaldırılması için yabani türlerimizin kültüre alınması gerekmektedir. Seleksiyon aşamasından sonra, yabani türlerin kültüre alınmasının en önemli adımlarından birisi ise etkili bir vejetatif çoğaltma metodunun geliştirilmesi olacaktır.

Bu çalışmada, üretimi zor olan bitkiler için hızlı bir teknik olarak görülen, bitkinin vejetatif üretiminin yaygınlaştıran, aynı form ve özellikte binlerce bitki elde edilebilen, ayrıca ticari üretim için uyumunun hızlı olduğu bilinen doku kültürü yöntemi literatürlerden faydalanılarak açıklanmıştır. Ayrıca, potansiyel süs bitkisi olması yanında tıbbi bitki ve gıda bitkisi olarak da kullanılabilen bazı doğal türlerimizin doku kültürü ile üretimi çalıșmalarımızdan örneklere yer verilmiștir. Böylece üretimi zor olan doğal türlerimizin çoğaltılmasına, nesli tükenmekte olan özellikle endemik türlerimizin koruma altına alınmasına, biyoçeşitliliğimizin korunmasına yönelik yapılacak çalışmalara 1şık tutmak hedeflenmiștir.

Anahtar Kelimeler: Doku kültürü, süs bitkisi, tıbbi bitki, gıda bitkisi

\section{Use of Tissue Culture Techniques in the production of natural plant species in Turkey}

\begin{abstract}
Turkey, with the number of native species it has in terms of floristic richness, is one of the leading countries in the world ranking. Besides their aromatic, pharmacological, medical and food use; some of these types are highly valuable as ornamental plants for landscape architecture. The majority of our species has not been taken or could not have been taken into the culture yet, they just stay in the rural landscape as wild species. In addition, increasing population and growing industrialization have led to deterioration in the habitat of these natural plants and some of the species are even endangered because of the fact that they are picked irresponsibly and heavily in the nature. To eliminate these unfavorable situations, our wild species must be taken into the culture. After the selection phase, one of the most important steps in the culture of wild species will be the development of an effective vegetative production method.

In this study; tissue culture method, a rapid technique for the plants that are difficult to produce and which extends the vegetation production, obtains thousands of plants with the same form and characteristics and is also known with its rapid alignment for commercial production, is described by making use of the literature. Additionally, examples from our works in the production of some of our native species, which can be used as medicinal plants and food plants in addition to being ornamental plants, with the tissue culture method are also included in the study. Hence, this study aims to provide an insight to the reproduction of native species that are hard to produce, the protection of species, particularly the endemic species, that are in danger of extinction and the studies for the protection of our biodiversity.
\end{abstract}

Keywords: Tissue culture, ornamental plants, medical plants, food plants

\footnotetext{
${ }^{1}$ e-mail: fatih.bekiryazici@erdogan.edu.tr
} 


\section{Giriş}

Ülkemiz odunsu ve otsu türler açısından değerlendirildiğinde, bu türlerin farklı biyocoğrafik bölgelerde ve farklı yetişme koşullarında oluşturduğu kompozisyonlarda zengin bir potansiyele sahip olduğu görülmektedir. Türkiye'nin birbirinden farklı iklim ve toprak koşullarına sahip çeşitli bölgelere ayrılmış olması ve Güneybatı Asya ile Güney Avrupa arasında bir köprü görevi görmesi; çeşitli kültür bitkilerinin ve Avrupa'da yabani olan türlerin birçoğunun ana vatanının Anadolu olması da bu potansiyelin asıl sebebidir [3].Ülkemiz bitki tür çeşitliliği açısından oldukça zengindir. 12 bin adet civarından fazla bitki taksonu (tür, alt tür, varyete, melez, vb.) bulunmaktadır. Bunun 3642'si endemik taksondur. Bu endemik taksonların birçoğunun peyzaj mimarlığında kullanılabilme potansiyeli bulunmaktadır [4].

1996 y1lında imzalanan ve Türkiye'nin de taraf olduğu CITES sözleşmesine göre; taraf ülkeler "yabani hayvanların ve bitkilerin çok çeşitli ve güzel biçimleriyle yeryüzünün doğal sistemlerinin yeri doldurulamaz bir parçası olduğunu ve gerek mevcut gerekse gelecek kuşaklar için korunmasının zorunlu olduğunu kabul etmişlerdir [22].

Bulunduğumuz zaman göz önüne alındığında sadece ekonomik değere sahip türlerin üretimi, araştırılması ve bu türler üzerine yoğunlaşılması, diğer bitki türlerinin ihmal edilmesi anlamına gelmemelidir. Dünya, biyoçeşitliliğin korunması yönünde çalışmalar yapmaktadır. Bunun için ekonomik değeri yüksek olan türlerimizi üretmenin yanı sıra, diğer bitki türlerine gereken önem verilmelidir. Bu nedenle tüm bitki türlerinin üretimine yönelikte araştırmalar hızlandırılmalıdır [16].

Ekonomik değeri diğer türlere göre düşük olan, ancak kozmetik, ilaç, gıda, boya ve kimya sanayide kullanılabilen bitkiler Peyzaj Mimarlığı olmak üzere pek çok alanda da geniş kullanım potansiyeline sahiptir. Bu türlerin bir kısmı kolayca üretilebilirken, bir kısmı üretimindeki bazı problemlerden dolayı kolayca üretilememektedir. Üretimindeki bu zorluklardan dolayı nesli yok olmaya yüz tutmuş birçok kıymetli doğal türümüzün de olduğu bilinmektedir. Üretiminde zorluklar bulunan bu türler için klasik üretim yöntemleri dışında etkili bir vejetatif üretim yönteminin geliştirilmesi oldukça önem arz edecektir. Böylelikle hem gittikçe artan ihtiyaçlara karşıllık verilebilecek, hem de bu türlerin nesillerinin yok olmasının önüne geçilebilecektir.

Üretimi zor olan bitkiler için hızlı bir teknik olarak görülen doku kültürü yönteminin uygulanması ile bitkinin vejetatif üretiminin yaygınlaşacağı, kısa sürede üretimin gerçekleştirilebileceği, aynı form ve özellikte binlerce bitki elde edilebileceği, ayrıca ticari üretim için uyumunun hızlı olduğu bilinmektedir [10]. Ayrıca, diğer vejetatif çoğaltma metotları ile karşılaştırıldığında in vitro mikroçoğaltım en etkili çoğaltma metodu olur [12].

Vike ve Habjorg [20], doku kültürü ile vejetasyon süresine ve tohuma bağlı kalmadan, bitkinin herhangi bir dokusundan yıl boyunca sürekli üretim gerçekleştirildiğini çalışmalarında ortaya koymuşlardır. Kaya [15], doku kültürü tekniği ile seçilmiş genotiplerin değerlendirilmesi, hızlı büyüyen fertlerin ortaya çıkarılması, soğuğa, kuraklığa, hastalıklara, tuzluluğa ve herbisitlere dayanıklı üstün bireylerin ortaya çıkarılmasının mümkün olabileceğini çalışmalarında göstermiş̧tir.

Bu çalışmada, üretiminde zorluklar içeren doğal türlerimizin doku kültürü yöntemleri kullanılarak etkili bir vejetatif çoğaltma metodunun geliştirilmesi, böylelikle üretimdeki zorluklarının ortadan kaldırılması, ayrıca zamana bağlı kalmadan daha hızlı, daha seri ve aynı anda aynı özelliğe sahip (doku, form) binlerce bitkinin üretilmesiyle park bahçelerimize kazandırılması, ilaç ve besin sanayisi için hammadde temin edilmesi, hususunda yapılacak çalışmalara ışık tutulması amaçlanmıştır. 


\section{Doku Kültürü İle Üretim Yöntemleri}

Bitki doku kültürü yöntemi, temelde bir üretim yöntemidir. Bilinen diğer klasik üretim yöntemlerinden farklı olarak, bitkinin çeşitli kısımlarından alınan küçük bir doku parçasını (eksplant) sterilize edildikten sonra, çeşitli besin maddelerini içeren steril besi ortamına (in vitro) ve uygun çevre koşullarında (1şık, rutubet ve sıcaklık) kültüre alınması işlemidir [13, 18-20].

Doku kültürü ile ilgili çalışmalar, 1975 yılına kadar kallus kültürü ile bitki rejenerasyonu esasına dayandırılmıştır [8]. In vitro tekniklerinin, sağladığı olanaklar şu şekilde sıralanabilir:

In vitro teknikleri; tipik genotiplerin hızlı üretimi, dayanıklılık için in vitro’ da erken seleksiyon, klasik vejetatif çoğaltma için gençleştirme, hastalıksız bitki elde edilmesi, haploit bitkilerin üretilmesi, mutantların üretimi ve seçimi, genetik çeşitliliğin saklanması (soğuk saklama ve dondurarak saklama), somatik embriyo oluşumu ve sentetik tohum üretimi, protoplast kültürü ile in vitro' da somatik hibridizasyon, DNA teknolojisi ile gen transferi vb. olanaklara sahiptir [7, 19-20].

Diğer taraftan doku kültürü ile üretimi vejetasyon dönemine bağlı olmaması, bir klonu sınırsız bir şekilde üretme olanağı vermesi, poliploit bireyler elde edebilme ve gen bankaları (doku bankaları) kurma gibi yararları yanında, çelikle üretilmesi zor olan bazı bitki türlerinin bu yöntemle kolayca üretilmesi, zengin tohum yıllarının seyrek olduğu ve tohumların uzun süre saklanmasının mümkün olmadığı veya güç olduğu ağaç türlerinin üretilmesinde de önem taşımaktadır [20].

Genetikçiler doku kültürü tekniğini, seçilmiş genotiplerin değerlendirilmesinde, hızlı büyüyen fertlerin ortaya çıkarılmasında, soğuğa, kuraklığa, hastalıklara, tuzluluğa ve herbisitlere dayanıklı bireylerin seçilmesinde etkin bir şekilde kullanırlar [15]. In vitro teknikleri ile nispeten problemsiz ve hızlı üretim ihtimali, daha ileri ıslah adımlarında kullanılabilecek önemli avantajlar sunmaktadır [19].

Doku kültüründe kullanılan bazı besin ortamları [11, 19-20] :

WS: Wolter ve Skoog besi ortamı, WPM: Woody Plant Medium besi ortamı, MS: Murashige ve Skoog besi ortam1, DKW: Driver ve Kuruyuki besi ortamı, SH: Shenk ve Hildebrand besi ortamı, GD: Gresshoff ve Doy besi ortamı, DL: Durzan ve Lopushansk besi ortamı ve LS: Linsmaier ve Skoog besi ortamı şeklinde sıralanabilir. $\mathrm{Bu}$ besin ortamlarından bazılarını oluşturan komponentlerin konsantrasyonları Tablo 1'de verilmiştir.

Tablo 1. Bitki Doku Kültüründe En Çok Kullanılan Temel Besin Ortamları ve Bu Ortamlardaki Bileşimlerin Konsantrasyonları

Bileşimler
$\mathrm{NO}_{3}$
$\mathrm{NH}_{4} \mathrm{NO}_{3}$
$\mathrm{NH}_{4} \mathrm{H}_{2} \mathrm{PO}_{4}$
$\left(\mathrm{NH}_{2} \mathrm{SO}_{4}\right.$
$\mathrm{MgSO}_{4} \cdot 7 \mathrm{H}_{2} \mathrm{O}$
$\mathrm{CaCl}_{2} \cdot 2 \mathrm{H}_{2} \mathrm{O}$
$\mathrm{Ca}\left(\mathrm{NO}_{3}\right)_{2} \cdot 4 \mathrm{H}_{2} \mathrm{O}$
$\mathrm{KCl}$
$\mathrm{KH}_{2} \mathrm{PO}_{4}$
$\mathrm{NaH}_{2} \mathrm{PO}_{4} \cdot \mathrm{H}_{2} \mathrm{O}$
$\mathrm{NaH}_{2} \mathrm{PO}_{4}$
$\mathrm{Na}_{2} \mathrm{SO}_{4}$
$\mathrm{MnSO}_{4} \cdot \mathrm{H}_{2} \mathrm{O}$
$\mathrm{MnSO}_{4} \cdot 4 \mathrm{H}_{2} \mathrm{O}$
$\mathrm{Kl}$
$\mathrm{H}_{3} \mathrm{BO}_{3}$
$\mathrm{ZNSO}_{4} \cdot 7 \mathrm{H}_{2} \mathrm{O}$
$\mathrm{CuSO}_{4} \cdot 5 \mathrm{H}_{2} \mathrm{O}$

MS
1900
1650
-
-
370
440
-
-
170
-
-
-
-
22.3
0.83
6.2
8.6
0.025
Kültür Ortamındaki Konsantrasyonu(mg/1)

BS
2500
-
-
134
250
150
-
-
-
150
-
-
10
-
0.75
3.0
2.0
0.025$$
134
$$$$
250
$$$$
150
$$$$
-
$$$$
150
$$$$
\text { - }
$$$$
\text { - }
$$$$
0.75
$$$$
\begin{aligned}
& 3.0 \\
& 2.0
\end{aligned}
$$

0.025

$\begin{array}{ccc}\text { LS } & \text { WHITE S-3 } & \text { NN } \\ 1900 & 80.0 & 950 \\ 1650 & - & 720 \\ - & - & - \\ - & - & - \\ 370 & 720 & 185 \\ 440 & - & 220 \\ - & 300 & - \\ - & 65 & - \\ 170 & 68 & 68 \\ - & - & - \\ - & 16.5 & - \\ - & 200 & - \\ 16.89 & - & - \\ - & 7.0 & 25 \\ 0.83 & 0.75 & - \\ 6.2 & 1.5 & 10 \\ 10.58 & 3.0 & 10 \\ 0.025 & - & 0.025\end{array}$


Dinçer D., Bekçi B., Bekiryazıcı F.

\begin{tabular}{|c|c|c|c|c|c|}
\hline $\mathrm{Na}_{2} \mathrm{MoO}_{4} \cdot 2 \mathrm{H}_{2} \mathrm{O}$ & 0.25 & 0.25 & 0.25 & - & 0.25 \\
\hline $\mathrm{CoCl}_{2} 6 \mathrm{H}_{2} \mathrm{O}$ & 0.025 & 0.025 & 0.025 & - & - \\
\hline $\mathrm{FeSO}_{4} .7 \mathrm{H}_{2} \mathrm{O}$ & 27.8 & 27.8 & 27.85 & - & 27.8 \\
\hline $\mathrm{Fe}_{2}\left(\mathrm{SO}_{4}\right)_{3}$ & - & - & - & 2.5 & - \\
\hline Sequestrene 330 & - & - & - & - & - \\
\hline $\mathbf{F e}$ & - & - & - & - & - \\
\hline $\mathrm{Na}_{2}$ EDTA & 37.3 & 37.3 & - & - & 37.3 \\
\hline Nikotinik Asit & 0,5 & 1.0 & - & - & 5 \\
\hline Pridoksin. HCl & 0,5 & 1.0 & - & - & 0.5 \\
\hline Thiamin. HCl & 0,1 & 10.0 & 0.4 & - & 0,5 \\
\hline Biotin & - & - & - & - & 0.05 \\
\hline Folik Asit & - & - & - & - & 0.5 \\
\hline Myo-inositol & 100 & 100 & - & - & 100 \\
\hline 1-inositol & - & - & 100 & - & - \\
\hline Glisin & 2.0 & - & - & - & 2.0 \\
\hline Glutamin & - & - & - & - & - \\
\hline Sakkaroz & 30.000 & 20.000 & - & - & 20.000 \\
\hline
\end{tabular}

Günümüzde in vitro’ da, çeşitli bitki türlerinin doku kültürü tekniği ile üretilmesinde; Kallus kültürü, organ kültürü, embriyo kültürü, hücre ve protoplast kültürü kullanılmaktadır [1, 17, 18- 20].

\subsection{Kallus Kültürü}

Kallus kültürü explantlardan uygun bir besin ortamında kallus dokusunun oluşturulması yani izole edilmiş hücre yığınlarının steril kültürüdür. Kallus kültüründe bitkinin bölünebilme özelliğine sahip hücrelerin bulunduğu bitki kısımlarından başlanabilir. Bunlara örnek olarak; endosperm, polen, embriyo, yaprak sapı, kök kısımları, internodlar vs. verilebilir [20]. Kallus kültüründe kallusun oluşabilmesi için ortama genel olarak 2, 4-D eklenir [14 ve 20].

\subsection{Organ Kültürü}

Doku kültürü teknikleri ile üretimde pratik ormancıllğa uygulanabilirlik bakımından ve genetik stabiliteyi sağlamak açısından en çok kullanılan yöntem organ kültürüdür [1 ve 2]. Organ kültüründe sürgün oluşumu ve bitki rejenerasyonunda; yapraklar, kotiledon ve hipokotil gibi embriyo parçaları, sürgün ve sürgün uçları, koltuk ve terminal tomurcukları gibi bitkinin değişik kısımları materyal olarak kullanılmaktadır [19].

\subsection{Embriyo Kültürü}

Embriyo kültürü izole edilmiş, olgun veya olgunlaşmamış embriyoların in vitro da gelişmesi veya muhafaza edilmesi olarak tanımlanır. Ortamdaki karbonhidratlar embriyonun ayakta kalması ve büyümesini büyük ölçüde artırırlar. Sakkarozdan daha yaygın olarak kullanılan karbonhidratlar, sadece enerji kaynağı değil, aynı zamanda osmotik düzenleyici olarak kullanılır. Embriyo kültürü orman ağacı türlerinde geniş oranda çimlenme engelinin ortadan kaldırılması için kullanılmaktadır [20].

\subsection{Hücre Kültürü}

Hücre kültüründe alınan hücre tek olabileceği gibi hücre grupları da olabilir. Hücre kültürü kağıt ve petri kabı tekniği olmak üzere iki şekilde yapılır. Kağıt tekniğinde aktif kallustan mikropipetle alınarak kağıt üstüne koyulan tek hücre bölünerek sürgün ve kök oluşumu yapar. Daha sonra yeni ortamlara taşınır. Petri kabı tekniğinde sterilize edilmiş besin ortamı ile karıştırılan hücre grupları özel bir steril ortamdan geçirilerek farklı ebatlardaki kaplara taşınır. Son olarak ta petri kabına aktarılıp kültüre alınır. Köklenen sürgünler yeni ortamlar taşınır [20]. 


\subsection{Protoplast Kültürü}

Hücre çeperi kimyasal işlemlerden geçirilip yok edilerek protoplast elde edilir. İki ayrı bitkiden elde edilen iki protoplast aynı ortamda kültüre alınarak ikisinin kaynaşması sonucu yeni bir bitki yani hibrid oluşur. Protoplast izolasyonu mekanik izolasyon, enzimatik izolasyon olmak üzere iki şekilde yapılır. Protoplastlardan bu yolla vejetatif melezleme yapılarak çok sayıda bitki elde edilebilir [20].

\section{Doku Kültürü Yöntemi İle Bitki Üretim Aşamaları}

\subsection{Hazırlık Aşaması}

Materyalin alınması ve besin ortamı içine atılmasını kapsar. Petri kapları veya tüpler içerisinde bulunan ortama, dezenfekte edilmiş materyal yerleştirilir. Daha sonra ortamlara yerleştirilen bitkiler sabit sıcaklık ve 1 şık koşullarına sahip iklim dolaplarında büyüme gelişme ve çoğalmaya bırakılırlar (Şekil 1)

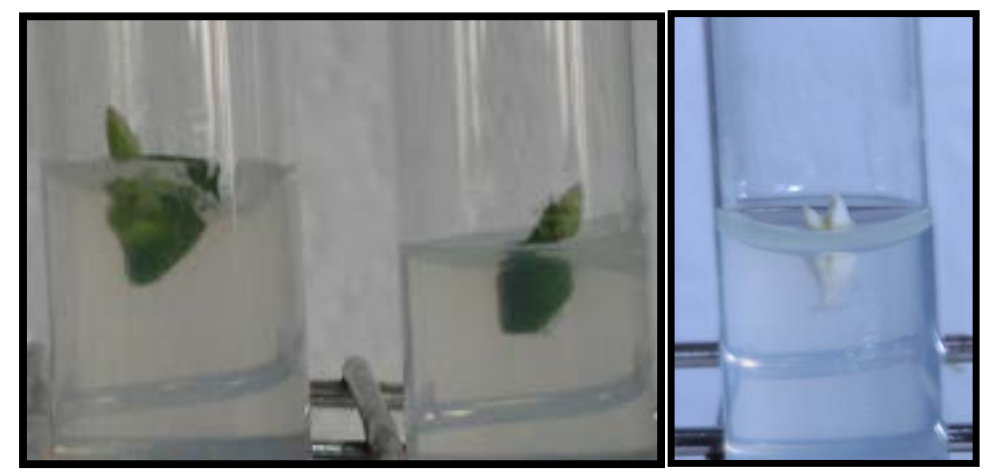

Şekil 1. Kültüre alınmış Crataegus sp. ve Sorbus sp. Taksonları [6 ve 9]

\section{2. $\quad$ Sürgün Așaması}

Materyalin kültüre alımından sonra çoğaltımda kullanılan bitki tür ve çeşidinin çoğalabilme özelliğine bağlı olarak çeşitli sayıda yeni sürgün meydana gelmektedir. Bu sürgünler ayrılarak daha geniş kaplar içerisinde alt kültürlere alınırlar. Köklendirme aşamasına geçilene kadar alt kültüre devam edilir.
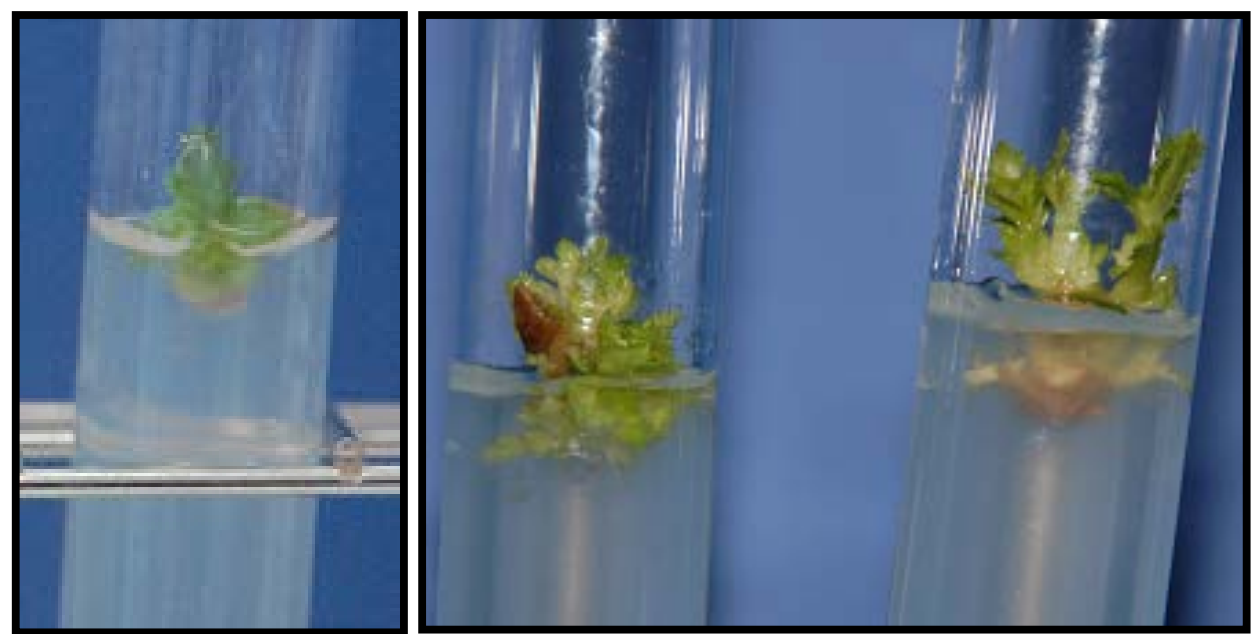
Dinçer D., Bekçi B., Bekiryazıcı F.

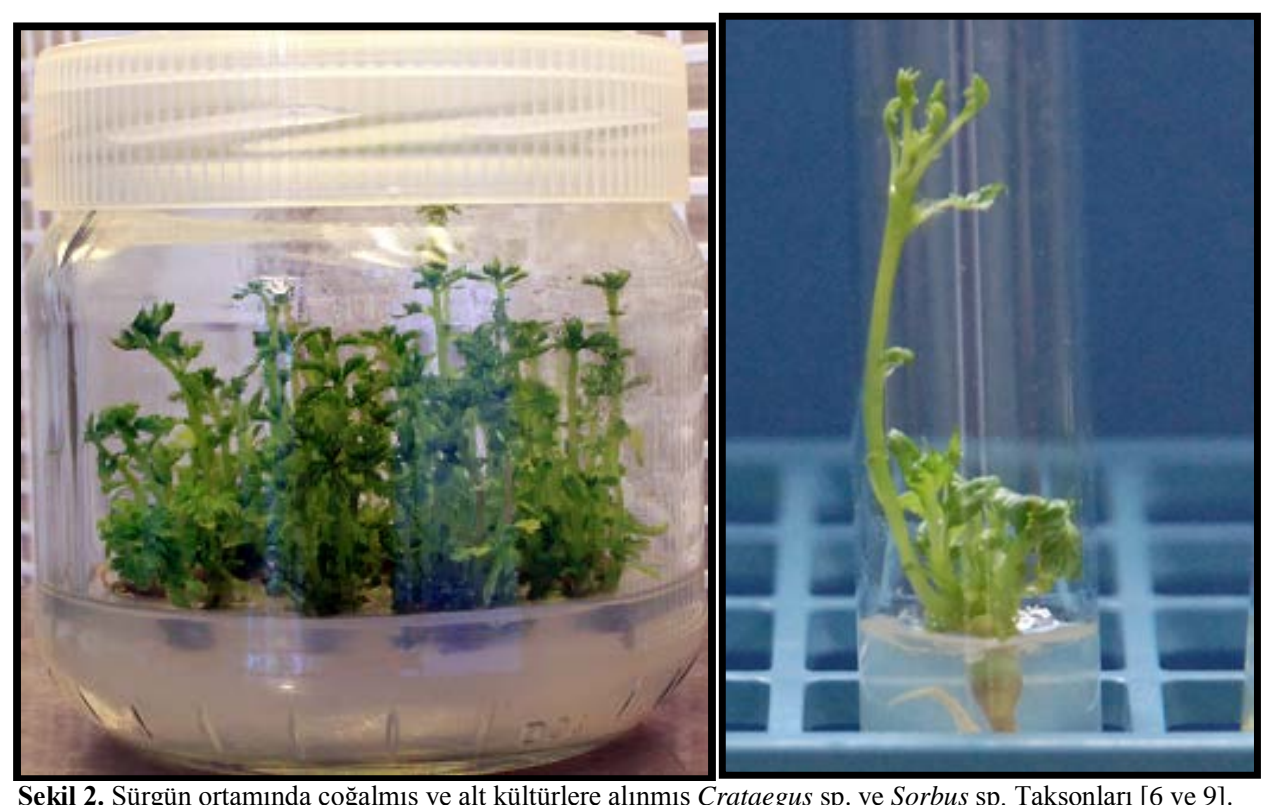

3.3. Köklendirme Aşaması: Besi ortamının büyümeyi düzenleyici madde içeriği değiştirilerek sürgünler köklendirme ortamında kültüre alınırlar. Kullanılan materyale göre besi ortamı kuvveti de belirli oranlarda azaltılabilir (Şekil 3).

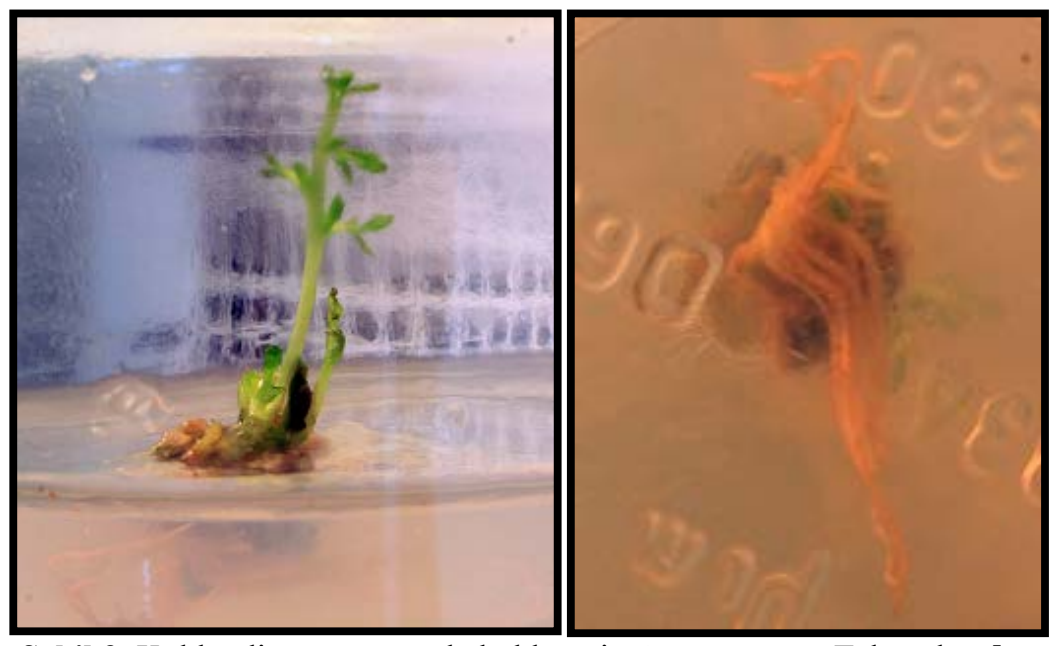

Şekil 3. Köklendirme ortamında köklenmiş Crataegus sp. Taksonları [9].

\subsection{Toprağa Şaşırtma}

Köklenen bitkicikler toprağa aktarıldıktan sonra nem kaybını önlemek için belirli süre iklim dolabında bekletilir, daha sonra sera ortamına alınır (Şekil 4). 


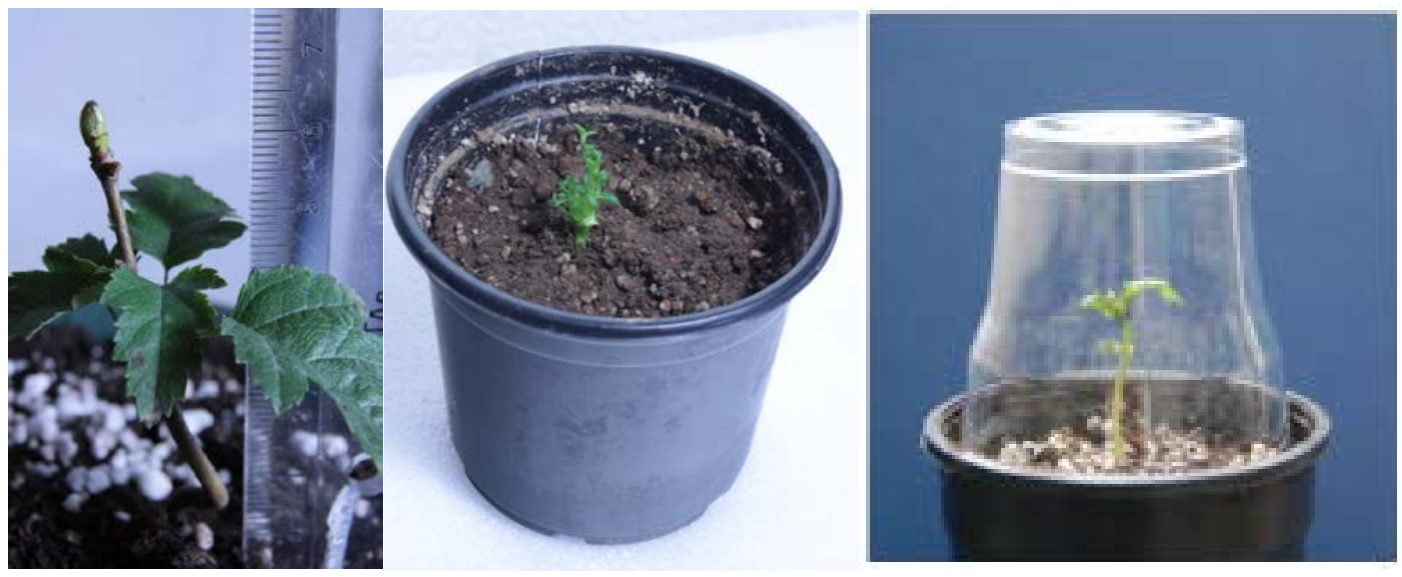

Şekil 4. a) Sorbus sp. nin dış ortama alıştırılmasından bir yıl sonraki görünümü b) Şeffaf örtüsü kaldırılan Sorbus sp. den bir görünüm ve c) İlk 15 gün şeffaf örtü ile toprağa alıştırılan Sorbus sp. den bir görünüm [6].

\section{Sonuçlar}

$\mathrm{Bu}$ çalışmada, özellikle üretiminde zorluklar içeren doğal türlerimizin, doku kültürü yöntemleri kullanılarak etkili bir vejetatif çoğaltma metodunun geliştirilmesi, böylelikle üretimdeki zorluklarının ortadan kaldırılması, zamana bağılı kalmadan daha hızlı, daha seri ve aynı anda aynı özelliğe sahip (doku, form) binlerce bitkinin üretilmesiyle park bahçelerimize kazandırılması, ilaç ve besin sanayisi için hammadde temin edilmesi, bunun sonucunda da ülke ekonomisine ve yöre halkına katkı sağlayacak doku kültürü yöntemi açıklanmıştır. Doku kültürü yöntemi açıklanırken üretiminde zorluklar içeren, iki değerli türümüz Crataegus sp. ve Sorbus sp. nin doku kültürü ile üretim çalışmalarından örnekler verilerek, bu yönteme dikkat çekilmesi ve daha sonra yapılacak çalışmalara ışık tutulması hedeflenmiştir.

\section{Kaynaklar}

[1] Ahuja, M. R., "Application Of Brotechnology to Forest Tree Species and Problems Involved" Holzwirtschaft, 154, 187-199, 1986

[2] Ahuja, M.R., “Aspen” Techniques and Applications, New York, 4, 1986

[3] Akdoğan, G., "Orta Anadolu Step Bitki Örtüsünde Bulunan Bazı Otsu Bitkilerin Peyzaj Planlamasında Değerlendirme İmkanları Üzerine Bir Araştırma” Köy İşleri Bakanlığı 1972

[4] Arslan, N., Endemik Tibbi Bitkilerimiz, II. Tıbbi ve Aromatik Bitkiler Sempozyumu, Yalova, 2014

[5] Babaoğlu, M., Gürel, E., Özcan, E., "Biyiteknolojisi, I. Doku Kültürü ve Uygulamaları" Selçuk Üniversitesi Vakfi Yayınları, 374 s, 2002

[6] Bekci, B., "Peyzaj Mimarlığında Değerlendirme Potansiyeli Olan Akçaağaç Yapraklı Üvez (Sorbus torminalis L. Crantz)'ın Generatif ve Vejetatif Yöntemler Kullanılarak Uretimi” Doktora Tezi, Fen Bilimleri Enstitüsü, KTÜ, Trabzon, 2010

[7] Bhojwani, S.S. ve Razdan, M.K., "Plant Tissue Culture Theory and Practice" Elsevier Science Publishers B.V., Netherlands, 1983

[8] Chalupa, V., "European Hardwoods” Cell and Tissue Culture in Forestry, 3, The Netherlands, 1987 
[9] Dinçer, D., "Peyzaj Mimarlığında Önemli Doğal Alıç Taksonlarımızdan Crataegus pontica C. Koch Verh. ve Crataegus meyeri Pojark.'ın Bazı Doku Kültürü Teknikleri ile Üretimi” Doktora Tezi, Fen Bilimleri Enstitüsü, KTÜ, Trabzon, 2010

[10] Galle, F.C., “Azaleas” Timber Press, 1987

[11] George, E.F., Puttock, D.J.M. ve George, H.J., "Plant Culture Media” Formulations and Uses, Volume I, Exegetics Limited, England, 1987

[12] Gökbunar, L. “Alıç (Crataegus sp.)’ın in vitro Mikroçoğaltımı” Yüksek Lisans Tezi, Kahramanmaraş Sütçü İmam Üniversitesi, Fen Bilimleri Enstitüsü, Kahramanmaraş, 2007

[13] Gönülşen, N., “Bitki Doku Kültürleri Yöntemleri ve Uygulama Alanları” T.C. Tarım ve Köy İşleri Bakanlığı Ege Tarımsal Araştırma Enstitüsü Müdürlüğü, Yayın No:78, Menemen-İzmir, 1987

[14] Harbage, J.F. ve Stimart, D. P., “Adventitious Shoot Regeneration from in vitro Subcultured Callus of Rhododendron Exbury Hybrids” Hort Science, 22, 6, 1324-1325, 1987

[15] Kaya, Z., "Doku Kültürünün Orman Ağaçları Islah Çalışmalarındaki Yeri” Orman Müh. Dergisi, 25, 5, 12-19, 1988

[16] Koçak, M., “Bazı Sorbus L. (Üvez) Türleri Tohumlarının Çimlenme ve Fidecik Gelişimi Üzerine Hormonal İşlemin Etkisi” Yüksek Lisans Tezi, Gazi Üniversitesi, Fen Bilimleri Enstitüsü, Ankara, 2006

[17] Pierik, R. L. M., “In Vitro Culture Of Higher Plants” The Netherlands, 1986

[18] Srivastava, P. S. ve Steinbaver, A., "Regeneration Of Birch Plants Catkin Tissue Cultures” Plant Science Letters, 22, 1981

[19] Üçler, A.Ö., “Titrek Kavak (Populus tremula L.) ve Kafkas Ihlamumuru (Tilia rubra DC.)’ nun Doku Kültürü Teknikleri ile Üretilmesi” Doktora Tezi, K.T.Ü., Fen Bilimleri Enstitüsü, Trabzon, 1994

[20] Vidalie, H., "In Vitro Culture and Its Applications In Horticulture” Economic Botany, 51, 1, 92-93, 1986

[21] Vike, E. and Habjorg A., "Variation in Fluoride Content and Leaf Injury on Plants Associated with Three Aluminium Smelters in Norway” Science of The Total Environment, 163, 1-3, 25-34, 1995 Yayın No: 198, Toprak Su Genel Müdürlüğü Yayını, Sayı 282, Ankara

[22] Yiğit, N., Çolak, E., Ketenoğlu, O., Kurt, L., Sözen, M., Hamzaoğlu, E., Karataş, A., Özkurt, Ş., “Çevre Etki Değerlendirme (ÇED)" Çevre Ve Orman Bakanlığı, Ankara, 2002 